\title{
Слободнозидарска библиотека Савеза Уједињених Великих ложа Србије
}

\author{
Горан Траиловић \\ Градска библиотека Панчево \\ goran@biblioteka-pancevo.org.rs
}

\begin{abstract}
Сажетак
Слободнозидарска библиотека Савеза Уједињених Великих ложа Србије (Савез УВлС) прикупља публикације које се односе на слободно зидарство и тематику која је повезана са његовим духовним вредностима, као и дела писаца који припадају овом „секуларном братском друштву“. Реч је, колико је познато, о првој и јединој (регистрованој) масонској библиотеци у региону. Смештена је у Храму Савеза УВЛС у Београду и спада у специјалне библиотеке општег типа. Библиотека је део јединственог библиотечко-информационог система Републике Србије и интернационалног удружења Масонских библиотека и музеја (MLMA). Фонд библиотеке још увек није инвентарисан ни обрађен. Могу га користити чланови Ложе, а под одређеним условима и заинтересовани истраживачи. На основу поузданих извора и личног увида, аутор даје податке о њеном фонду, организацији и раду.
\end{abstract}

Кључне речи: слободно зидарство, масони, библиотека, Србија, Слободнозидарска библиотека Савеза Уједињених Великих ложа Србије, Београд, Удружење масонских библиотека и музеја (MLMA)

\section{Увод}

Слободно зидарство једно је од најстаријих светских секуларних братских друштава, удружење „људи са високим моралним и духовним вредностима“. Његови обреди су приватног карактера, а као и многа друга удружења, оно своје унутрашње активности сматра приватном ствари својих чланова. ${ }^{1}$ Иако постоје бројна нагађања и мистификације у јавности, не постоји никаква тајна у погледу његових циљева и принципа. Они су јавно прокламовани и доступни на веб-презентацијама масонских ложа. ${ }^{2}$

Библиотеке у Србији, у својим фондовима, чувају велики број публикација које се односне на масонерију ${ }^{3}$ и оне имају своје читаоце. Многи од њих желе да завире у свет „тајних друштава“4 и сазнају нешто више о слободним зидарима и њиховој организацији старој више векова.

\footnotetext{
${ }^{1}$ Савез Уједињених Великих ложа Србије, „Слободно зидарство“, преузето 25. 6. 2018, http://www.lodge.rs/.

${ }^{2}$ Судећи према истраживању објављеном у новом броју Неимара, у свету постоји скоро 500 ложа у виртуелном простору. Види: Бр. П. Б., „Интернет и масонерија“, Неимар бр. 28-29 (септ-дец 6017. Г.И.С. [2017]): 52-53.

Циљеви и принципи масонерије нису се мењали од оснивања првих ложа. Рекло би се да је, кроз време, само јачала или слабила њена моћ да их спроведе. Утицај је зависио и зависи од друштвених околности и утицаја самих чланова. Јасно је да је моћ неке ложе много већа ако су њени чланови крунисане главе, кнезови или председници држава и влада. Јасно је и да је морална и духовна снага масонерије у директној зависности од поштовања сопствених принципа и пажње коју поклањају пријему нових чланова, „добрих људи на добром гласу“.

${ }^{3}$ О слободном зидарству и његовим принципима видети нпр, у уводном делу студије Зорана Ненезића, Масони у /уїославији: (17641980): ирреілеg истиорије слобо оної зияарсишва у Іуїославији: иррилози и ірађа (Београд: Народна књига, 1984), или на веб-страници: Savez UVLS, Informator o slobodno-zidarskom bratstvu, preuzeto 25. 6. 2018, http://www.lodge.rs/wp-content/uploads/2016/06/SLOBODNO-ZIDARSTVO-INFORMATOR.pdf.

Како су многи писци и научници били масони, библиотеке чувају и њихова дела, а гледано у историјској вертикали, „тајни састанци масона" су се некада одржавали у објектима у којима су сада смештене библиотеке (нпр. у згради у Кнез Михаиловој улици број 56, у којој се некада налазио хотел „Српска круна“, а у којој је, од октобра 1986. смештена Библиотека града Београда, Библиотека града Београда, „Зграда БГБ-а“, преузето 25. 6. 2018, http://www.bgb.rs/index.php/2011-11-14-21-02-05/pr-s-ri/zgr-d).

${ }^{4}$ Мада слободно зидарство није тајно друштво, већ „друштво са тајном“ како истичу његови чланови. Видети поменуту студију 3. Ненезића и Informator o slobodno-zidarskom bratstvu, одељци „Tajnost" и "Pitanje tajnosti društva”.
} 
Једна од најчитанијих књига у Србији средином осамдесетих година била је Масони у лу-

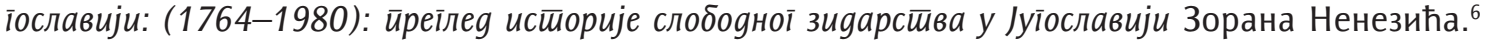
Она је на светло дана изнела једну, до тада, „забрањену тему“, а читаоце је посебно занимао регистар на њеном крају, како би утврдили ко је припадао масонским ложама у Југославији.

Ни шира ни стручна библиотекарска јавност нису много упознате са чињеницом да у Београду постоји библиотека која прикупља публикације које се односе на слободно зидарство и тематику која је повезана са његовим духовним вредностима, као и дела писаца који припадају овом „секуларном братском друштву“. Реч је о Слободнозидарској библиотеци Савеза уједињених великих ложа Србије (Савез УВЛС). ${ }^{7}$

\section{О библиотеци}

Библиотека је постала део јединственог библиотечко-информационог система Републике Србије крајем 2017. године и једна је од преко 500 регистрованих библиотека којима је матична и над којима врши стручни надзор Библиотека града Београда. Реч је, колико је познато, о првој специјализованој масонској библиотеци у региону. Смештена је у Храму Савеза УВЛС у Београду и спада у специјалне библиотеке општег типа. Под „надзором“ је Савеза, а о њој брину Литерарни одбор (раније у Уједињеној великој ложи Србије - одбор за библиотеку) и Велики Библиотекар. ${ }^{8}$

Статус библиотеке је сродан статусу Савеза УВЛС, организације у којој је формирана. ${ }^{9} \mathrm{Pe}-$ гистрована је и делује у складу са Законом о библиотечко-информационој делатности, ${ }^{10}$ битне информације о њој су јавно доступне, али не и њени фондови и приступ самој библиотеци. ${ }^{11}$ Њена мисија је да „обезбеди едукативни материјал на тему масонерије и сродних предмета“

\footnotetext{
${ }^{5}$ И земљама које су припадале Социјалистичкој Федеративној Републици Југославији (СФРЈ).

${ }^{6}$ Ненезић, Масони у Іуїославији... Аутор је касније објавио више томова нових прилога и грађе које се тичу историје слободног зидарства у Југославији.

${ }^{7}$ Регистрована је 7. 12. 2017. године (рег. број СП-4588/95). Библиотека града Београда, Одељење за унапређење библиотечке делатности, „Записник о извршеном надзору над стручним радом“ бр. 5905 (15. 12. 2017), 1-4.

Док је аутор овога текста трагао за релевантним изворима о овој библиотеци и контактом са надлежним у Савезу УВлС, појавила се у дневном листу Данас краћа изјава (бившег) великог мајстора УвЛС и Савеза УвЛС Петра Радоњанина, у којој се помиње ова библиотека. - Katarina Živanović, "Iako ima i ministara, masoni se ne bave politikom“, Dnevni list Danas, rubrika "Društvo", 6. juna 2018, preuzeto 16. 7. 2018, https://www.danas.rs/drustvo/iako-ima-i-ministara-masoni-se-ne-bave-politikom/. Посета библиотеци и разговор са новим законским заступницима помогао је да се снађем у новонасталој ситуацији. Заинтересовани могу наћи јавно доступне информације о дешавањима у УВЛС, односно Савезу УВЛС у документима Агенције за привредне регистре, у штампи и на интернету.

${ }^{8}$ Како је наведено: „...програми и активности библиотеке се организују кроз Одбор за библиотеку У.В.Л.С., којим председава Велики библиотекар. Библиотеком руководи директор библиотеке“. Уједињене велике ложе Србије, „Слободно зидарска библиотека УВлС", преузето 25. 6. 2018, https://www.uvls.org.rs/biblioteka_uvls.html. На веб-странама Савеза УВЛС не налазимо информације о Библиотеци, али смо од секретара ове ложе сазнали да о библиотеци формацијски брине Велики Библиотекар, да је планирано да има два помоћника, а да је функција директора библиотеке укинута.

У Конституцији Савеза УВЛС, донете 23. 6. 2017. у члану 11. наводи се да „Велики Секретар у координацији са Великим Архиваром и Великим Библиотекаром, управља целокупном Архивом и Библиотеком Велике Ложе; и води инвентар целокупне њене имовине“. - Савез УВЛС, Конституција Савеза УВЛС, чл. 11. (Београд, 2017)

Осим званичног Статута организације, који се ни формом, ни одредбама, ни стилом не разликује од статута других удружења грађана, и који не помиње њену библиотеку, као интерни документ, постоји Масонски статут Савеза УВЛС, који даље разрађује поменуту Конституцију. Он у члану 45. говори о постојању Литерарног Одбора „састављеног од пет лица, које бира Велики Библиотекар од чланова Ложа“, а у члану 46. истиче да се Литерарни Одбор „брине да Библиотека Велике Ложе буде снабдевена свим важнијм слободнозидарским делима и часописима у свету. У том циљу Велика Ложа уноси у свој годишњи предрачун потребна средства; а евентуалне набавке за то врши Велики Секретар. - Савез УВЛС, Масонски статут Савеза УВЛС, чл. 45. и 46. (Београд 2017).

${ }_{9}^{9}$ Савез УВлС је, као удружење, регистрован у Агенцији за привредне регистре Србије под матичним бројем 28189028 (датум оснивања 7. 12. 2015) и подаци о њему су јавно доступни, укључујући и имена заступника, битна документа и финансијске извештаје. Информације о библиотеци која је предмет овог текста и издавачкој делатности се и даље налазе само на адреси Уједињених великих ложа Србије (УВЛС), „Слободно зидарска библиотека УВЛС“. То што и даље делује УВЛС (матични број у АПР -у 17714058; основана 18. 5. 2007), која нема везе са библиотеком, може збунити неупућене.

10 Закон о библиотечко-информационој делатности, Сл. іласник PC бр. 52 (2011), преузето 26. 6. 2018, https://www.nb.rs/view_file. php?file_id=3047.

${ }^{11}$ Што је у складу са чл. 53. Закона о библиотечко-информационој делатности: „(2) Коришћење фондова специјалних библиотека је ограничено на одређене корисничке групе, зависно од типа организације у чијем саставу је образована, односно зависно од специфичног типа корисника."
} 
првенствено за чланове Савеза УВЛС. ${ }^{12}$ Заинтересовани истраживачи могу да је користе уз препоруку неког члана и одобрење надлежног органа, односно Великог Мајстора. ${ }^{13}$

Приликом регистрације, библиотекари Одељења за унапређење библиотечке делатности Библиотеке града Београда обавили су стручни надзор. У Записнику је констатовано да се библиотечки фонд и читаоница налазе у две међусобно повезане просторије у приземљу, укупне површине $40 \mathrm{M}^{2}$. Библиотека поседује „десет библиотечких столова за кориснике, петнаест столица, четири затворена библиотечка регала и три уградна полурегала са полицама за књиге укупне дужине 25 " $^{\prime \prime}$ и одговарајућу рачунарску опрему. ${ }^{14}$

За простор у коме се библиотека налази наводи се да је „нестандардне висине (изнад 2,60 м)". Она је, у ствари, смештена у пријатном клупском простору Ложе и књиге су, у сваком тренутку, доступне члановима (званично радно време библиотеке је од 10 до 14 часова). 3бог боље заштите, смештене су у затворене и застакљене витрине и чине складну целину са средишњим простором Храма. Још приликом његове градње планирана је библиотека и осмишљен адекватан простор за њу. ${ }^{15}$ Осим клупског простора у коме се може користити грађа, библиотека, односно Ложа, поседује и посебан простор читаонице у коме се налази „Зид Части“ са портретима српских великана који су били слободни зидари.

\section{О фонду}

Фонд библиотеке није инвентарисан ни обрађен, што је констатовано у поменутом Записнику, који наводи да се у њему налази 366 монографских публикација. Оне су сређене „по УДК систему и у интерном распореду“. ${ }^{16}$ Реч је о лексикографским издањима и књигама са темама о симболизму, степенима и историји слободног зидарства, општој филозофији, историји, етици, религији... Такође се може пронаћи белетристика аутора који су слободни зидари. ${ }^{17}$ Део полица је означен плочицама које служе као упутни систем за кориснике ради лакшег сналажења („Историја и географија“, „Религија“, „Окултизам и астрологија“ итд.).

Реч је о релативно новим издањима. Изузетак је примерак старе и ретке књиге Opere drammatiche di Pietro Metastasio из 1825. године, која припада културним добрима од великог значаја. ${ }^{18}$

Према речима секретара Ложе, фонд је био нешто већи, али проблем невраћених публикација, који имају све библиотеке, није мимоишао ни ову. Однедавно се користе картони књига, како би могле да се задуже и раздуже, прати циркулација и на тај начин се чине покушаји да се заштити овај невелики, али вредан фонд. Књиге могу да задуже и изнесу из библиотеке само чланови Ложе.

Класификација, сигнирање, инвентарисање и други послови на стручном уређењу библиотеке тек следе или су недавно започети. Тренутно, о библиотеци брине секретар Ложе, који

\footnotetext{
12 Како се наводи у тексту посвећеном библиотеци Уједињених Великих ложа Србије, „Слободно зидарска библиотека УВлС“ (вебстраница је, како је на њој наведено, постављена 2009. и ажурирана до 2014. године). На веб-страници Савеза УВЛС који сада брине о библиотеци (покренутој 2016) још увек нема информација о њој. - Савез уједињених великих ложа Србије, преузето 25. 6. 2018, http://www.lodge.rs/.

${ }_{13}$ Тела Савеза УВлС су: Скупштина, Велики Мајстор, Велико Веће, Управно Веће, Ложа Великих Официра, Суд Части. Титула „Велики Мајстор“ традиционално означава особу која руководи Ложом, Председник је Удружења и њен је законски заступник. Опширније на веб-страници Савез Уједињених Великих ложа Србије, „Велика ложа“.

У Статуту СУВЛС наведено је да уз Скупштину постоје следећи органи Удружења: Управни одбор, Председник и Извршни одбор (Статут Саеза УВЛС од 23. 6. 2017). Традиционалне титуле су у овом акту, дакле, замењене уобичајеним називима за органе управљања удружења грађана.

${ }^{14}$ Библиотека града Београда, Одељење за унапређење библиотечке делатности, 2.

15 Храм Уједињених Великих ложа у Београду, освећен 2008, први је слободнозидарски Храм подигнут у Србији после Другог светског рата. Опширније на веб-страници Уједињених Великих ложа Србије, „Уједињена Велика ложа Србије“ (реч је о подацима који се односе на простор у коме је смештен Савез УВлС и његова библиотека).

${ }^{16}$ Библиотека града Београда, Нав. дело.

17 Уједињене Велике ложе Србије, „Слободно зидарска библиотека УВлС“.

18 Библиотека града Београда, Нав. дело.
} 
ће, у најскорије време, предати дужност новом Великом Библиотекару. Планирано је да он добије и два помоћника како би се стручни послови што пре завршили ${ }^{19}$ и како би библиотека несметано функционисала.

Грађа се, према поменутом Записнику, као и у другим библиотекама, набавља путем поклона, размене и куповине. У скорије време очекује се већа донација књига на страним језицима. Она броји готово дупло више књига него што их библиотека Савеза тренутно има у фонду.

У библиотеци се чувају и издања УВЛС, односно Савеза УВЛС: Прируиник за сва йри сйейе-

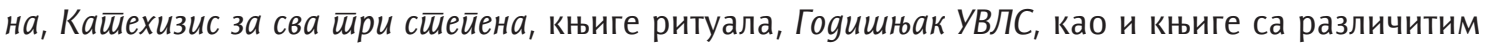
слободнозидарским темама које су писали аутори - чланови ложе. ${ }^{20}$ Ова литература је неопходна за савладавање едукативних курсева које сви квалификовани официри ложа морају да заврше.

Уз различите „дипломе и масонске документе“, Савез УвЛС објављује и часопис Неимар, као свој званични тромесечни гласник. ${ }^{21}$ У њему читаоци могу да пронађу поруке Великог Мајстора, вести из ложа, новости из масонског света, радове које су писала браћа, обавештења Великог Секретаријата ложе, текстове о историји разних Великих Ложа, чланке о масонском симболизму, филозофији, уметности и ритуалима, здравствене савете, приказе књига итд. Неимар се дели бесплатно свим члановима Ложе и дистрибуира масонским библиотекама широм света. Није нам познато да, осим библиотеке Савеза УВЛС, нека јавна или специјална библиотека поседује примерке овог гласила. Може се наћи у Народној библиотеци Србије и Библиотеци Матице српске.

\section{Удружење Масонских Библиотека и Музеја}

Библиотека је члан интернационалног удружења Масонских библиотека и музеја (Masonic Library and Museum Association - MLMA) са седиштем у Сједињеним Америчким Државама. ${ }^{22}$ Оно је основано 1995. и има мисију да, путем едукације и на сваки други начин, помаже, подржава и повезује активности које су посвећене прикупљању, управљању и заштити масонског наслеђа. Информативна и прегледна веб-страница (и Фејсбук група) снажно подржавају ову

19 Што подразумева и доношење Правилника о раду библиотеке, вођење статистике издатих књига и броја корисника итд.

${ }^{20}$ Ujedinjene Velike lože Srbije, "Slobodno zidarsko izdavaštvo Ujedinjenih Velikih Loža Srbije“, preuzeto 25. 6. 2018, https://www.uvls. org.rs/izdavastvo_uvls.html.

${ }^{21}$ Неимар је било име првог званичног гласника Велике Ложе Југославије који је излазио од 1914. до 1926. године, када му је име промењено у Шесшар. Под тим именом наставио је да излази све до успављивања Велике Ложе Југославије 1940. године. Настављајући традицију прве масонске публикације у Србији, УВЛС је обновио њено издавање и тако назвао своју публикацију. Уједињене Велике ложе Србије, „Часопис НЕИМАР званични тромесечни гласник Уједињених Великих Ложа Србије“, преузето 25. 6. 2018, https://www.uvls.org.rs/neimar.html,Ова напомена се може наћи и у самој публикацији.

Први број часописа објављен је у децембру 2010, а актуелни (дво)број 28-29, датиран „септ-дец 6017 Г.И.С“, почетком 2018. Њега потписује смењени уређивачки савет са Петром Радоњанином на челу. На новој веб-страници Савеза (http://www.lodge. rs/), у одељку "Издаваштво“, могу се наћи бројеви 19 и 20 у PDF формату. У плану је постављање свих бројева на сајт, као и репринт предратних издања. Неимар је од конституисања Савеза УВЛС њен званични гласник.

Дигитализоване предратне копије Неимара доступне су на веб-страници Народне библиотеке Србије, Дигитална народна библи-

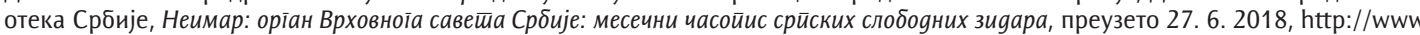
digitalna.nb.rs/sf/NBS/casopisi_pretrazivi_po_datumu/P_0316.

На веб-страници НБС се може наћи дигитализовано и предратно издање масонског часописа Шесшар (1921-1939), Дигитална

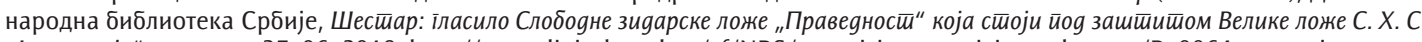
"луїославија", преузето 27. 06. 2018, http://www.digitalna.nb.rs/sf/NBS/casopisi_pretrazivi_po_datumu/P_0964, а у узајманом каталогу постоји информација о покретању интерног гласила Регуларне велике ложе Србије Нови шестиар: месеини билшен РВЛС, 2004. године. Заинтересовани на веб-страници Велике националне ложе Србије (https://www.mason.org.rs/) могу наћи е-часопис Сиријус (покренут 2009) и друга издања.

22 Како је наведено на веб-страници Уједињених Великих ложа Србије, Уједињене Велике ложе Србије, „Слободно зидарска библиотека УВЛС“. У то смо се уверили увидом у листу чланова MLMA (Institutional Members) где је уписана као United Grand Lodges of Serbia - Masonic Library. Masonic Library \& Museum Association, Membership List, preuzeto 27. 6. 2018, http://www.masoniclibraries.org/membershiplist.php.

Пун назив организације је: The Masonic Library and Museum Association: An International Organization of Librarians, Archivists, Curators, and Directors (MLMA). - Masonic Library \& Museum Association, By-laws of the MLMA, преузето 27. 6. 2018, http:// www.masoniclibraries.org/bylaws.php. 
мисију, а постоји и имеил група за ефикасну и брзу комуникацију између чланова, захтеве за литературом и слично. Ту су и линкови на каталоге масонских библиотека (и WorldCat), најаве и обавештења о годишњим ${ }^{23}$ и специјалним скуповима асоцијације, чак и кратки курсеви за библиотекаре и кустосе, упутства за припрему изложби, чување (масонске) грађе и наслеђа итд.

Чланови асоцијације су већином америчке масонске библиотеке и музеји и масонске ложе, али има и института и сродних установа, као и ложа и масонских библиотека широм света (Канаде, Аргентине, Бразила, Енглеске, Шкотске, Данске, Норвешке, Румуније, Италије, Немачке, Аустралије, Новог Зеланда....). ${ }^{24}$ Чланство у овој асоцијацији је библиотеци Савеза УВЛС пружило велике могућности повезивања и сарадње са масонским библиотекама, музејима и институтима на глобалном нивоу.

\section{Закључак}

Слободно зидарска библиотека Савеза Уједињених Великих ложа Србије је прва регистрована специјализована масонска библиотека у региону. Спада у специјалне библиотеке општег типа и, уписом у Регистар библиотека, постала је део јединственог библиотечко-информационог система Републике Србије. Чланством у интернационалном удружењу Масонских Библиотека и Музеја (MLMA) постала је и део глобалне заједнице масонских баштинских институција. Са јасном мисијом, добрим условима за рад, пажњом коју јој оснивач посвећује и вредним почетним фондом, она има све услове за несметан развој и напредак. Не може се, наравно, ни величином ни бројем публикација поредити са познатим масонским библиотекама у свету, попут House of the Темрle, ${ }^{25}$ Ливингстоновом библиотеком, ${ }^{26}$ Масонском библиотеком Rosend Arus $^{27}$ и другим, али има сродну мисију - да допринесе моралном и духовном уздизању њених корисника.

Приступ фонду је, као и код других специјалних библиотека, ограничен на одређену корисничку групу, у овом случају чланове Ложе. Ипак, она није потпуно затворена за „профане“ кориснике и истраживачи који нису чланови масонске организације могу је, под одређеним условима, користити. Постављењем новог Великог Библиотекара стварају се предуслови за реализацију развојних планова који предвиђају увећање фонда, његову стручну обраду и усаглашавање свих аспеката рада са одредбама закона и подзаконским актима који се односе на библиотечко-информациону делатност.

Значај библиотеке умногоме превазилази њен невелики фонд. Она може, на одређени начин (у виртуелном, ако не у физичком простору) постати место сусрета „профане“ публике и слободних зидара и тако утицати на отклањање предрасуда о „тајном друштву“. Може допринети и хармонизацији не баш складних односа у масонској заједници, њеном повезивању и сарадњи. Аутор овог текста процењује да неће проћи много времена и да ће се ова библиотека, са сада невеликим фондом, сусрести с проблемом који има већина библиотека у Србији - недостатком простора (које ће дигитализација, е-књиге, банке података и међубиблиотечка позајмица моћи само да ублаже). То ће бити разлог више да се размишља о већем простору и озбиљно размотри идеја изградње заједничког храма свих ложа и слободних зидара који делују у Србији, а у коме ће књигохранилиште имати своје важно место.

\footnotetext{
23 Последњи је одржан од 11. до 13. октобра 2018. у Спрингфилду (Илиносис, САД).

24 Чланови MLMA, иначе, нису обавезно и масони и то није услов да се постане члан ове асоцијације.

25 The Scottish Rite of Freemasonry, The House of the Tемple, About the Teмple, preuzeto 27. 6. 2018, https://scottishrite.org/ headquarters/about-the-temple/.

${ }^{26}$ The Chancellor Robert R Livingston Masonic Library of the Grand Lodge of New York, preuzeto 27. 6. 2018, http://nymasoniclibrary.org/.

${ }^{27}$ Atlas Obscura, Rossend Arús Masonic Library, preuzeto 27.6.2018, https://www.atlasobscura.com/places/rossend-arus-masonic-library.
} 


\section{Литература и извори:}

1. Agencija za privredne registre Srbije. Objedinjena pretraga. Preuzeto 27. 6. 2018. http://pretraga2.apr. gov.rs/unifiedentitysearch.

2. Atlas Obscura. Rossend Arús Masonic Library. Preuzeto 27. 6. 2018. https://www.atlasobscura.com/ places/rossend-arus-masonic-library.

3. Biblioteka grada Beograda. „Zgrada BGB-a“. Preuzeto 25. 6. 2018. http://www.bgb.rs/index. php/2011-11-14-21-02-05/pr-s-ri/zgr-d.

4. Biblioteka grada Beograda, Odeljenje za unapređenje bibliotečke delatnosti. „Zapisnik o izvršenom nadzoru nad stručnim radom" br. 5905 (15. 12. 2017), 1-4.

5. Masonic Library \& Museum Association. By-laws of the MLMA. Preuzeto 27. 6. 2018. http://www. masoniclibraries.org/bylaws.php.

6. Masonic Library \& Museum Association. Membership List. Preuzeto 27. 6. 2018. http://www. masoniclibraries.org/membershiplist.php.

7. Narodna biblioteka Srbije. Digitalna Narodna biblioteka Srbije. Neimar: organ Vrhovnoga saveta Srbije: mesečni časopis srpskih slobodnih zidara. Preuzeto 27. 6. 2018. http://www.digitalna.nb.rs/sf/NBS/ casopisi_pretrazivi_po_datumu/P_0316.

8. Narodna biblioteka Srbije. Digitalna Narodna biblioteka Srbije. Šestar: glasilo Slobodne zidarske lože "Pravednost" koja stoji pod zaštitom Velike lože S. H. S. "Jugoslavija". Preuzeto 27. 6. 2018. http://www. digitalna.nb.rs/sf/NBS/casopisi_pretrazivi_po_datumu/P_0964.

9. Nenezić, Zoran D. Masoni u Jugoslaviji: (1764-1980): pregled istorije slobodnog zidarstva u Jugoslaviji: prilozi i građa. Beograd: Narodna knjiga, 1984.

10. P. B., Br. „Internet i masonerija“. Neimar br. 28-29 (sept-dec 6017. G.I.S. [2017]: 52-53.

11. Savez Ujedinjenih Velikih loža Srbije. Informator o slobodno-zidarskom bratstvu. Preuzeto 25. 6. 2018 http://www.lodge.rs/wp-content/uploads/2016/06/SLOBODNO-ZIDARSTVO-INFORMATOR.pdf.

12. Savez Ujedinjenih Velikih loža Srbije. „Izdavaštvo“. Preuzeto 25. 6. 2018. http://www.lodge.rs/.

13. Savez Ujedinjenih Velikih loža Srbije. Konstitucija Saveza UVLS. Beograd, 2017.

14. Savez Ujedinjenih Velikih loža Srbije Masonski statut Saveza UVLS. Beograd, 2017.

15. Savez Ujedinjenih Velikih loža Srbije. "Slobodno zidarstvo“. Preuzeto 25. 6. 2018. http://www.lodge.rs/.

16. Savez Ujedinjenih Velikih loža Srbije. Statut Saveza UVLS. 23. 6. 2017.

17. Savez Ujedinjenih Velikih loža Srbije. „Velika loža“. Preuzeto 25. 6. 2018. http://www.lodge.rs/.

18. Ujedinjene Velike lože Srbije. „Časopis NEIMAR zvanični tromesečni glasnik Ujedinjenih Velikih Loža Srbije“. Preuzeto 25. 06. 2018. https://www.uvls.org.rs/neimar.html.

19. Ujedinjene Velike lože Srbije. "Slobodno zidarska biblioteka UVLS“. Preuzeto 26. 6. 2018. https:// www.uvls.org.rs/biblioteka_uvls.html.

20. Ujedinjene Velike lože Srbije. "Slobodno zidarsko izdavaštvo Ujedinjenih Velikih Loža Srbije”. Preuzeto 25. 6. 2018. https://www.uvls.org.rs/izdavastvo_uvls.html.

21. Ujedinjene Velike lože Srbije. „Ujedinjena velika loža Srbije“. Preuzeto 25. 6. 2018. https://www.uvls. org.rs/velika_loza.html.

22. The Scottish Rite of Freemasonry, The House of the Темple. About the Tемple. Preuzeto 27. 6. 2018. https://scottishrite.org/headquarters/about-the-temple/.

23. The Chancellor Robert R Livingston Masonic Library of the Grand Lodge of New York. Preuzeto 27. 6. 2018. http://nymasoniclibrary.org/.

24. Velika nacionalna loža Srbije. Sirijus. Preuzeto 27. 6. 2018. https://www.mason.org.rs/.

25. Zakon o bibliotečko-informacionoj delatnosti. Sl. glasnik RS br. 52 (2011). Preuzeto 26. 6. 2018. https://www.nb.rs/view_file.php?file_id=3047.

26. Živanović, Katarina. „Iako ima i ministara, masoni se ne bave politikom“. Dnevni list Danas, rubrika "Društvo", 6. juna 2018. Preuzeto 16. 7. 2018. https://www.danas.rs/drustvo/ iako-ima-i-ministara-masoni-se-ne-bave-politikom/. 


\title{
Masonic Library of The Alliance of United Grand Lodges of Serbia
}

\begin{abstract}
Summary
The Masonic Library of The Alliance of United Grand Lodges of Serbia collects publications related to Freemasonry and topics related to its spiritual values as well as the works of writers belonging to this secular fraternity. As far as it is known, it is the first and only (registered) Masonic library in the region. The library is located in the Temple of The Alliance of United Grand Lodges of Serbia in Belgrade. It is a special library of general type. The library is a part of the unified library-information system of the Republic of Serbia and the international association of Masonic Libraries and Museums (Masonic Library and Museum Association - MLMA). The library fund has not yet been inventoried or processed. It can be used by the members of the Lodge, and under certain conditions, by interested researchers. Based on reliable sources and personal insights, the author gives information about the library fund, its organization and work.
\end{abstract}

Keywords: Freemasonry, Masons, library, Serbia, Masonic Library of The Alliance of United Grand Lodges of Serbia, Belgrade, Masonic Library and Museum Association (MLMA) 


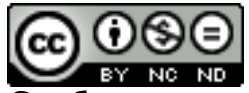

Слободнозидарска библиотека Савеза Уједињених Великих ложа Србије bу Горан Траиловић is licensed under a Creative Commons Attribution-NonCommercial-NoDerivatives 4.0 International License. 